\title{
Effect of Eucalyptus Globules Woodlot Plantation on Selected Soil Physico-Chemical Properties and Wheat Yield in Wogera District, Amhara Region, Ethiopia
}

\author{
Kassegn Asnakew Seyoum ${ }^{1 *}$, Bekalu Melis Alehegn ${ }^{1}$, and Asmamaw Alemu Abtew ${ }^{2}$ \\ ${ }^{1}$ College of Agriculture and Natural Resource, Assosa University, Assosa, Ethiopia \\ ${ }^{2}$ College of Agriculture and Environmental science, University of Gondar, Gondar, Ethiopia
}

\begin{abstract}
Currently, a Eucalyptus globule is a common smallholder plantation species in the Wogera district. The species is significantly expanding on marginal and fertile farmlands. The objective is to analyze the effects of Eucalyptus globules woodlots plantation and their directions on selected soil physicochemical properties and yield of wheat crop. Three woodlots with similar site conditions were selected for this particular study. Soil samples were taken at a soil depth of 20 $\mathrm{cm}$ in RCBD design with three replications. Soil samples were taken at four directions (East, West, South, and North) of woodlots plantation at five different horizontal distances from the woodlots; the center of the woodlot, $5 \mathrm{~m}, 10 \mathrm{~m}, 15 \mathrm{~m}$, and $40 \mathrm{~m}$. For the wheat yield study: Quadrates of $1 \mathrm{~m}^{2}$ area at each distance within directions were laid for wheat grain yield measurement. The finding indicated that electric conductivity, available phosphorus, cation exchange capacity, soil texture, and exchangeable cations were not significantly different across the different directions and distances, whereas soil bulk density, $\mathrm{pH}$, total nitrogen, organic matter were significantly different. This could be attributed to the high organic matter addition via litter-fall, root biomass, uptake, and return of nutrients from deeper soil profiles under the tree canopies. The biomass and grain yield of wheat were significantly different across distance and direction from the sampled woodlot in increasing trend in all directions, this study recommends Eucalyptus should planting on marginal lands with appropriate distance from croplands about $20 \mathrm{~m}$ to minimize its effect on crop yields.
\end{abstract}

\section{Keywords}

Eucalyptus, Soil properties, Wheat, Distance, Direction

\section{Introduction}

The Eucalyptus is the diverse genus of flowering plants in the globe. It belongs to the family Myrtaceae and comprises about 800 species [1]. Worldwide area coverage of Eucalyptus plantation was estimated at about 17.9 million hectares [2]. The species was introduced to East Africa in the late $19^{\text {th }}$ century and by the early 1970 s. Currently, Eucalyptus plantation covers about 12 million hectares overall in the tropical zone. In Ethiopia, Eucalyptus was introduced during the regime of Emperor Menilek II (1868-1907) in 1894/95 [3]. The purpose was to supply fuel wood and construction timber to the new and growing capital city, Addis Ababa. Currently, about 5 to 10 Eucalyptus species are commonly established for multipurpose uses [4]. Eucalyptus globules species are commonly planted on wide areas of land previously cultivated to crop production. Currently, an estimated area of 500.000 ha of the land is covered by Eucalyptus plantation in Ethiopia [5]. Among these, Eucalyptus globules plantations cover more than 100,000 ha that growing well at elevations ranging from 1400-3200 m.a.s.I. The major energetic factors that farmers to grown Eucalyptus are: Increasing demand for wood products in the market, high-income generation, high rate of biomass production, easy to establish, adaptability on infertile soils [6]. Farmers' increased their concentration in Eucalyptus plantation which caused the conversion of croplands into Eucalyptus plantation [7] However, the unrestrained expansion of Eucalyptus on productive croplands has a great alarm, due to the detrimental effects on soil productivity. Eucalyptus tree might cause crop yield loss through extract

*Corresponding author: Kassegn Asnakew Seyoum, Assosa University, College of Agriculture and Natural Resource, P.O.B 18 Assosa, Ethiopia

Accepted: June 11, 2021

Published online: June 14, 2021

Citation: Seyoum KA, Alehegn BM, Abtew AA (2021) Effect of Eucalyptus Globules Woodlot Plantation on Selected Soil Physico-Chemical Properties and Wheat Yield in Wogera District, Amhara Region, Ethiopia. J Soil Water Sci 5(1):161-170 
essential nutrients and compete with crops and impoverish the soil [8].

In recent years, the expansion of Eucalyptus globules plantation on and around the cropland is expanding from year to year in an alarming rate especially in northern Ethiopia highlands including the present study area. Increasing plantations would create competition among land area of crops and Eucalyptus globules woodlot plantations. Similar trends of replacement of cropland with Eucalyptus woodlots have been observed across Ethiopian highlands [4]. Reports showed that Eucalyptus trees change watercourses, soil physical and chemical properties, propensity to exhaust soil nutrients, and fertility eventually affects crop production and productivity [9]. However, the effects of Eucalyptus species on soil physical and chemical properties and exhaustion of the soil essential nutrients still remain unclear [10] and scientific reports are insufficient [6]. Therefore, additional documentation on the specific effects of Eucalyptus globules plantations in relation to crop yield and soil properties in the district is required. Thus, this study was undertaken with the aim to analyze the effects of Eucalyptus globules plantation on soil selected properties and wheat crop yield performances that grown neighboring to plantations. The results of the study can effectively create awareness for the community concerning specific effects of Eucalyptus globules tree species on crop performance and soil properties.

\section{Materials and Methods}

\section{Description of the study area}

The study was conducted in the Wogera district, it geographically situated at $12^{\circ} 46^{\prime} 06.5^{\prime \prime} \mathrm{N}$ and $37^{\circ} 37^{\prime} 26.5^{\prime \prime} \mathrm{E}$ in the North Gondar Zone of the Amhara region (Figure 1). It is situated about $32 \mathrm{~km}$ away from Gondar town and $213 \mathrm{~km}$ Northwest of Bahir Dar, the capital city of the Amhara region. The District covers an estimated area of $1821 \mathrm{~km}^{2}$. According to the Amhara Finance and Economic Development Bureau, 2012 the District has a total population of 250,493 out of this 127,858 are males and 122,635 are females, from the total population $94 \%$ live in rural areas, the population density is 137 people/km.

\section{Climate and soil type}

According to the agro-ecological classification of Ethiopia, the study area is characterized by three agro-climatic zones highland (56\%), Semi-lowland (26\%), lowland (14\%), and $4 \%$ frost (Wogera District agricultural office, 2013). The mean annual average temperature ranges between $14{ }^{\circ} \mathrm{C}$ to $33^{\circ} \mathrm{C}$. The rainfall pattern is orographic type, stretching from May to September. Annual average rainfall ranges between 1000 and $1600 \mathrm{~mm}$ which varies along the geographical zone. The District has an average altitude of 2812 meters above sea level (Wogera District agricultural office, 2013). Cambisol is the dominant soil type in the area and actually considered fertile soils [11]. They are deep, well-drained, red, tropical soils. However, the area is highly populated there is severe erosion in the area. Since the landscape has lost its natural vegetation, the soil of the surrounding hills is degraded with frequent rock outcrops.

\section{Land use and Land cover}

The major land uses of the study area include cultivated land, grazing land, and plantation of exotic species mainly Eucalyptus globulus. A large portion of the district is intensively cultivated land (Almost $68 \%$ of the land is under crop cultivation during cropping season). After crop

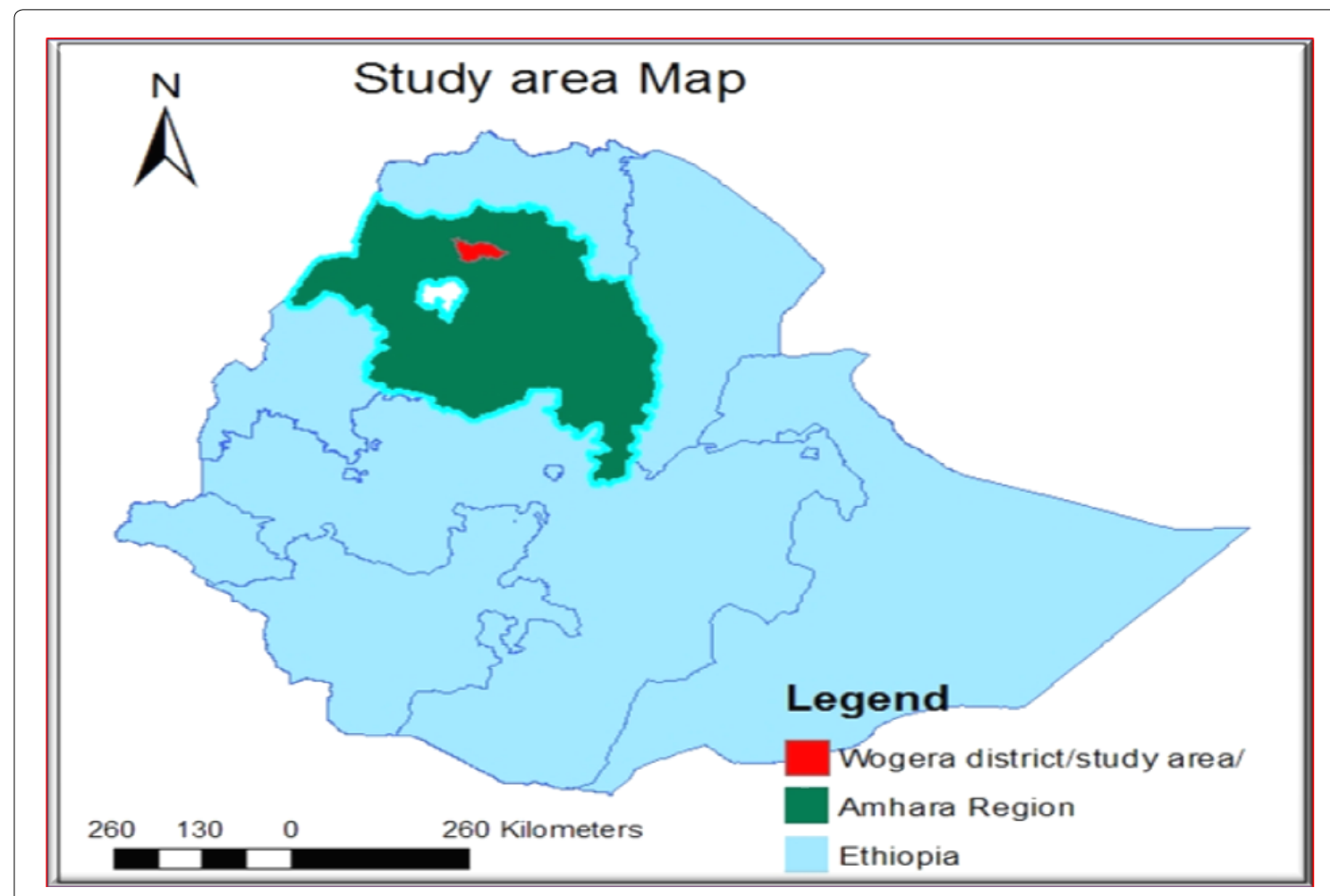

Figure 1: Map of the study area in the northwest Amhara region, Ethiopia. 
Citation: Seyoum KA, Alehegn BM, Abtew AA (2021) Effect of Eucalyptus Globules Woodlot Plantation on Selected Soil Physico-Chemical Properties and Wheat Yield in Wogera District, Amhara Region, Ethiopia. J Soil Water Sci 5(1):161-170

harvesting, the land is opened up for cropping and grazing livestock. Apart from a few trees around homesteads and farm borders, native trees are rarely seen in the landscape of the study area... The community faced a shortage of wood for construction and firewood, therefore most farmers adopt and expand Eucalyptus plantation on their land to alleviate the problems (Wogera District agricultural office, 2016).

\section{Livelihood}

The study area community mainly depends on mixed agriculture. Agriculture is characterized by crop oriented small-scale subsistence farming-system with a wide range of cereals, pulses crops grown for household consumption. Commercial farming mainly involves the growing of Eucalyptus globulus and some food crops such as chickpea. In spite of the fact that the diversified potential of crop productivity farmers has widely planted Eucalyptus globules on croplands, due to its fast growth and requires less care. The main plantation practices are woodlot, cropland boundary plantation, and road borders plantations to fulfill the needs for fuel wood, construction, and income generation.

\section{Sampling and data collection methods}

Combinations of methods were applied for the collection and analysis of data to meet the objectives of the study. Thus the selected and applied methods discussed in three categories below: i) Soil sampling and analysis techniques to evaluate the effect of selected physical and chemical properties and ii) The method used to evaluate the effect of the woodlots on crop yield along with different directions and distances.

Sampling of Eucalyptus globulus woodlot stands: The experiment was set on existing Eucalyptus woodlots plantation and their surrounding wheat crop... A reconnaissance survey was carried out through transect walk and then three Eucalyptus globules woodlot stands bordered by wheat crop were selected. The woodlots stand were selected purposely having nearly similar soil management practices, altitude, slope gradient, and Eucalyptus stand characteristics such as height, and diameter at breast height, age (all were $\approx 13-14$ years age). Measurements of three dimensions taken such as: Diameter at breast height using diameter tape, tree height using clinometer, and the crown diameter at crown base using a measuring tape. The slope gradient and elevation of the study area were measured by using a clinometer and global positioning system respectively (Table 1 ).

The plantations were established in 2005 and were harvested three times. The average area of the woodlots was 0.375 ha, ranging from 0.25 ha to 0.5 ha. All woodlots were owned by farmers and planted in an irregular pattern. The stand rotation age ranged from 4 to 5 years. Stand ages were 13-14 years and stand densities ranged from 9,500 to 12,000 individuals tree per ha.

Experimental design and data collection of crop yield: The test crop was wheat (Triticum aestivum), the most commonly grown crop variety within the study area. According to the farmer's crop calendar, the wheat crop was sown during 10 June to 25 June, 2016 and harvested at the end of December, 2016. The wheat crop was locally seeded $120 \mathrm{~kg}$ and fertilized with $100 \mathrm{kgha}^{-1}$ DAP (Di-Ammonium phosphate) and 100 $\mathrm{kgha}^{-1}$ Urea (nitrogen fertilizer at planting time). Most Farmers have practiced weeding three times. As described by development agents and local farmers, growers could harvest greater than 50 quintals ( 5 tons) per hectare.

Under farmers' crop production circumstances, the effects of Eucalyptus globules woodlot plantation on the neighboring wheat crop performances were assessed in the 2015/2016 cropping season. The fields experimental independent variable considered were the distances (at $5 \mathrm{~m}, 10 \mathrm{~m}, 15$ $\mathrm{m}$, and $40 \mathrm{~m}$ ) and direction (oriented north, south, east and west) of the Eucalyptus globules woodlot stand (Figure 2). At harvesting time, plot areas of $1 \mathrm{~m} * 1 \mathrm{~m}\left(1 \mathrm{~m}^{2}\right)$ were marked at $5 \mathrm{~m}, 10 \mathrm{~m}, 15 \mathrm{~m}$, and $40 \mathrm{~m}$ [12] far from the woodlot stand along with the four directions (East, West, North, and South)of the woodlot base. The $40 \mathrm{~m}$ distance represented the sampling point, which was assumed to be free from tree influence, and thus used as control. The experimental factors

Table 1: Characteristic features of the sampled Eucalyptus woodlot stands.

\begin{tabular}{|l|l|l|l|}
\hline \multirow{2}{*}{ Attributes } & \multicolumn{2}{l|}{ Sampled Eucalyptus globules stands } & \multicolumn{2}{l|}{ Stand 3 } \\
\cline { 2 - 4 } & Stand 1 & Stand 2 & 2 times coppice \\
\hline $\begin{array}{l}\text { Stand type (Coppice, standard } \\
\text { crop) }\end{array}$ & 2 times coppice & 2 times coppice & 13 \\
\hline Age (years) & 14 & 13 & 11 \\
\hline Average height (m) & 12.5 & 9.5 & 18 \\
\hline Average DBH (cm) & 20 & 16 & 7 \\
\hline Slope (\%) & 5.5 & 6.25 & 2961 \\
\hline Location (m.a.s.l) & 2955 & 2959 & Cropland \\
\hline Previous land use & Cropland & Cropland & Wheat cropland \\
\hline Surrounding land uses & Wheat cropland & Wheat cropland & 3 times \\
\hline Tillage frequencies & 3 times & 3 times & 100 kg DAP \\
\hline Rate of fertilizers (kg / ha & $100 \mathrm{~kg}$ DAP & $100 \mathrm{~kg}$ DAP & $100 \mathrm{~kg}$ Urea \\
\hline Soil texture & $100 \mathrm{~kg}$ Urea & $50 \mathrm{~kg}$ Urea & Clay loam \\
\hline Soil color & Loam & Clay loam & Blue \\
\hline Distance from homestead & Blue & Blue & $290 \mathrm{~m}$ \\
\hline
\end{tabular}




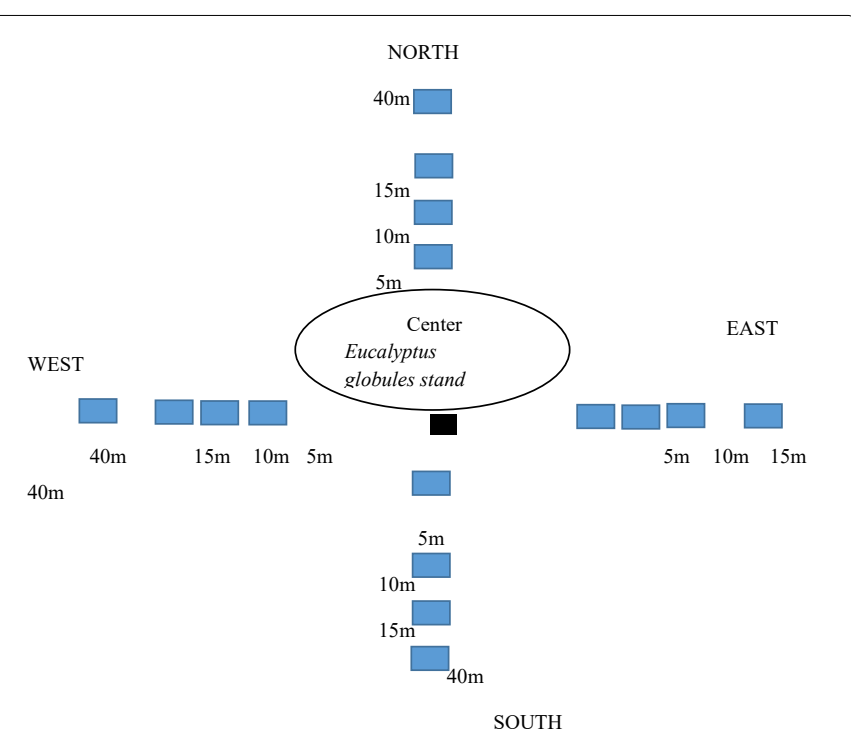

Figure 2: Schematic presentation of the field experiment design.

and levels were four directions and four distances, were arranged in RCBD (Random Complete Block Design) with three replications. Thus, a total of 48 ( 4 distance $\times 3$ woodlot $\times 4$ direction $\times 1$ depth) samples were collected.

Samples of wheat yield that grown at each sampled plot at harvesting time were collected at each distance in the four directions from the stand. The samples were air-dried, threshed manually, and then weighted the grain yield in grams in December, 2016. After the yield was determined, the total dry biomass yield was also measured in a similar way.

Soil sampling: The soil samples were collected in the 2016 cropping season after wheat crops have been harvested. A similar design was followed for wheat yield sampling illustrated in Figure 2. Moreover, the soil samples were collected at the center of the woodlot stands. The soil samples were collected from four corners of each plot $\left(1 \mathrm{~m}^{2}\right)$, with one from the center by auger from each laid distance and direction at the depth of $20 \mathrm{~cm}$. A total of 255 soil samples were collected from the three woodlot stands. Then the collected soil samples of the sub-plot (at the four corners and center) of the plot were thoroughly mixed to form a composite sample. In this way, a total of 255 soil samples were converted into 51 composite soil samples for convenient laboratory analysis.

\section{Soil Sample preparation and analytical procedures}

Before conducting the analysis, soil samples were airdried, then grinded and sieved through the 0.5 and $2 \mathrm{~mm}$ sieve to remove unwanted materials (crop/plant residue, gravels) from the sample except that of the bulk density sample. The soil samples were analyzed for chemical and textural properties at Gondar Soil Testing Laboratory using the following standard laboratory procedures [13]. Organic matter and total nitrogen contents of the soil were determined following the wet combustion method of the Walkley and Black method, and the wet digestion procedure of Kjeldhal method, respectively [14]. Available P was extracted by the Olsen method [15]. $\mathrm{P}^{\mathrm{H}}$ and Electric conductivity (EC) $(1: 2.5$, Soil:Water) of the soil were measured in water using a $\mathrm{pH}$ meter with a glasscalomel combination electrode [16]. Cation exchange capacity was determined following the 1nitrogen ammonium acetate method at pH 7 [17], and exchangeable calcium and magnesium were determined using EDTA (Ethylene diaminetetra acetic acid) titration, whereas exchangeable potassium and sodium were determined from the same extraction with flame photometry. Soil texture was determined by using bouyoucos hydrometer method. An undisturbed core sample from the topsoil was taken to determine the bulk density [18]. Soil samples were oven-dried at $105^{\circ} \mathrm{C}$ for bulk density determination.

\section{Data analysis}

Different analytical procedures were followed for the analysis of the two sets of crop yield and soil properties data. Analysis of variance using SAS (version 9) was performed to determine the effects of Eucalyptus globules woodlot plantation on parameters of both crops and soil properties to the entire woodlot direction and distance. All analyses were performed at a probability level of 0.05 , i.e., statistical differences were determined by two-way ANOVA employing a $95 \%$ level of confidence. Descriptive statistical procedures were also applied.

\section{Results and Discussion}

\section{Effect of Eucalyptus globules plantation on grain and biomass yield of wheat}

Eucalyptus globules plantations were assessed for their effect on the above-ground biomass and grain yield of wheat crop. The main effects (direction and distance) had a highly significant effect on the grain and biomass yield of wheat $(P<0.001)$ (Table 2$)$. The grain and biomass yield of wheat increased significantly as the distance $(10 \mathrm{~m})$ from the Eucalyptus stands increased in all directions (Figure 3).

The present findings concurred with that of [19] who concluded that the yield of wheat grain and straw increased significantly with an increase in distance from the stand. The increase in grain yield away from the woodlot could be due to less competition of nutrients, moisture, and shading effect under the woodlot canopies than the open fields. The maximum yield of wheat grain and biomass were 4893 and $5831 \mathrm{~kg} /$ ha respectively, recorded at the distance of $40 \mathrm{~m}$ away from the woodlot at the Eastern direction, while the minimum yield of grain and above ground-biomass were 2309 and $3772 \mathrm{~kg} / \mathrm{ha}$ respectively recorded the distance of $5 \mathrm{~m}$ away from the woodlot at the western direction (Table 2). Consistent with the present findings, [20] also reported that the adjacent tree decreased maize height and biomass by $42.9 \%$ and $74.6 \%$ respectively in Tanzania. Similarly [21] also reported that $40 \%$ of crop yield reductions when crops close to trees in Kenya.

The variation in grain and biomass yield between northern and southern directions was non-significant at respective woodlot plantation distance and direction. However, the grain and biomass yield between Eastern and Western directions varied significantly at all distances except $40 \mathrm{~m}$ (Table 3). 

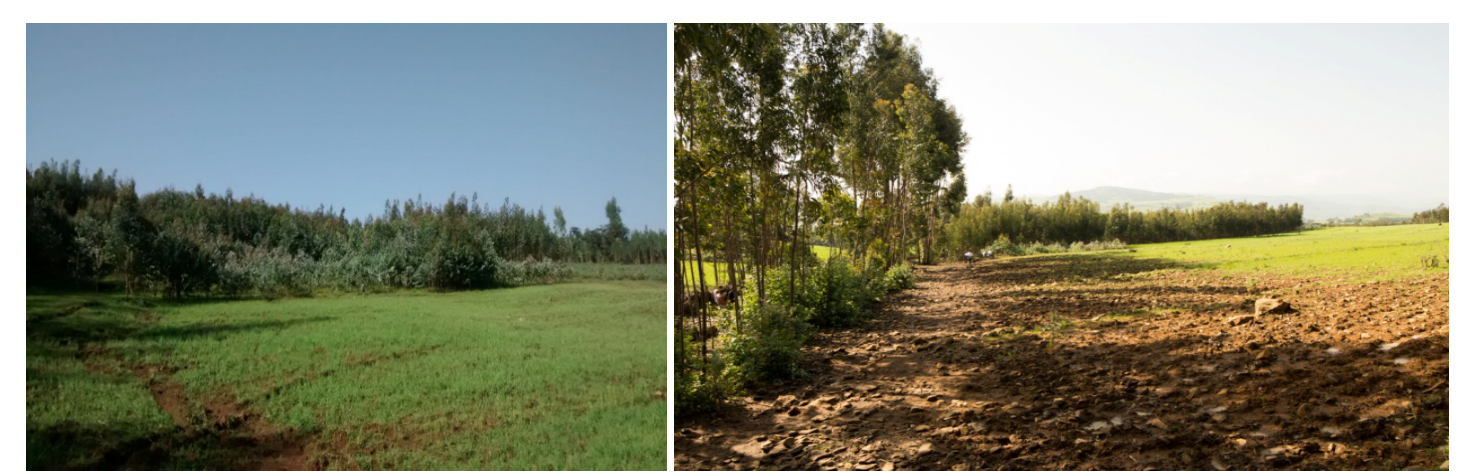

Figure 3: The morning shading effect of Eucalyptus globules plantation on croplands.

Table 2: Main effect of direction and distance on wheat crop yield.

\begin{tabular}{|l|l|l|l|}
\hline \multirow{3}{*}{ Components } & & \multicolumn{3}{|c|}{ Wheat yield } \\
\cline { 3 - 4 } & & Grain yield & $\begin{array}{l}\text { Biomass/ } \\
\text { straw/yield }\end{array}$ \\
\hline \multirow{5}{*}{ Directions } & East & $438.58 \mathrm{a}$ & $528.19 \mathrm{a}$ \\
\hline & West & $335.27 \mathrm{~b}$ & $447.40 \mathrm{~b}$ \\
\hline & South & $412.55 \mathrm{c}$ & $500.36 \mathrm{c}$ \\
\hline & North & $409.73 \mathrm{c}$ & $502.40 \mathrm{c}$ \\
\hline & LSD & 51.22 & 43.60 \\
\hline \multirow{5}{*}{ Distances } & Significant & & \\
\hline (m) & 5 & $335.71 \mathrm{a}$ & $437.57 \mathrm{a}$ \\
\hline & 10 & $370.24 \mathrm{a}$ & $472.50 \mathrm{~b}$ \\
\hline & 15 & $411.27 \mathrm{~b}$ & $503.53 \mathrm{c}$ \\
\hline & 40 & $478.91 \mathrm{c}$ & $564.75 \mathrm{~d}$ \\
\hline & LSD & 40.24 & 30.40 \\
\hline
\end{tabular}

Note: Column refers along a direction and rows refer distance with the same letters are not significantly different at $p<0.05$.

Table 3: Effect of Eucalyptus plantation on wheat grain and biomass yield (kg/ha).

\begin{tabular}{|c|c|c|c|c|c|}
\hline \multirow{2}{*}{ Parameters } & \multirow{2}{*}{ Directions } & \multicolumn{4}{|c|}{ Distance $(\mathrm{m})$ from the woodlot } \\
\hline & & 5 & 10 & 15 & 40 \\
\hline \multirow{6}{*}{ Grain yield } & East & $3927 a$ & $4200 b$ & $4521 c$ & $4893 d$ \\
\hline & West & $2309 b$ & $2644 c$ & $3813 d$ & $4643 e$ \\
\hline & North & $3600 a$ & $3873 b$ & $4109 c$ & $4805 \mathrm{e}$ \\
\hline & South & $3591 a$ & 4091c & $4006 c$ & $4813 e$ \\
\hline & CV (\%) & 2.69 & & & \\
\hline & LSD 0.05 & 17.85 & & & \\
\hline \multirow{6}{*}{$\begin{array}{l}\text { Biomass/ } \\
\text { straw/ } \\
\text { Yield }\end{array}$} & East & $4730 a$ & $5086 b$ & $5480 c$ & 5831d \\
\hline & West & $3772 b$ & $4032 b c$ & $4502 d$ & 5588ed \\
\hline & North & $4443 a$ & $4931 b$ & $5164 b$ & $5556 d$ \\
\hline & South & $4556 a$ & $4850 b$ & $4327 c$ & $5613 d$ \\
\hline & CV (\%) & 3.16 & & & \\
\hline & LSD 0.05 & 26.0 & & & \\
\hline
\end{tabular}

Note: Column refers along direction and a row refers distance with the same letters are not significantly different at $p<0.05$. The first letter represents significance comparison between distances and $b$ represent between directions.

The maximum crop and biomass yield was observed on the Eastern side of the woodlot stand base.

The interaction effect between distance and directions was significant (Table 3 ). There was a decline of nearly 35.3 and 52.8 percent of wheat grain and biomass yield respectively while comparing $5 \mathrm{~m}$ and $40 \mathrm{~m}$ intervals from the woodlot (Table 3). The effects of all directions at a $40 \mathrm{~m}$ distance were non-significant. These results are supported by other works, such as [22] that the high yield of wheat grain in areas without trees was presumably because of less competition of soil moisture, nutrients, and sunlight between agricultural crops and trees. They [23] studied the yield potential of inter-crop with Eucalyptus and its shading effect on adjoining wheat crops. The orientation of the tree line and the distance on which the associated crop they have grown contributed significantly towards crop growth and yield.

\section{Effect of Eucalyptus globules plantation on the physical properties}

Soil texture: According to the USDA textural classification, the texture of the area was clay loam soil. The sand proportions were (36.29\%), silt (34.67\%) and clay $(29.04 \%)$ (Table 4). The soil of the areas was predominantly sand (> $36.29 \%)$. The clay content in the soil was small (29.04\%). The mean silt proportion of the soil under the woodlot center was lower than the open farmland (Table 4). Soil texture might affect soil physical and chemical and to some extent soil biological properties, was not significantly affected (Table 4) across distance and direction from woodlot the texture is more related to parent material than tree influence. According to Landon [24], clay, clay-loam, and silt-loam soils show low bulk density values ( 1.0 to $1.6 \mathrm{gcm}^{-3}$ ) as compared to sands and sandy loam soils which show high bulk density values $\left(1.2\right.$ to $\left.1.8 \mathrm{gcm}^{-3}\right)$. The non-significant differences in the mean proportions of sand, silt, and clay fractions between the soils under the Eucalyptus woodlot and in the farmland suggests that the soils, are texturally similar, being clay loam and have derived from the same parent material, under the same climate, and similar topography.

Bulk density: The bulk density of the soils ranged from 1.13 (center of woodlot) to $1.34 \mathrm{gcm}^{-3}$ (Table 4), which categorized as low $[25,26]$ suggested that lower bulk density under Eucalyptus plantation which ranges 1.07 for topsoil for clay soil in the Amhara Regional State of Ethiopia. According to [27] lower bulk density under Eucalyptus plantation and Croton macrostachyus ranged 1.0 to $1.1 \mathrm{~g} / \mathrm{cm}^{-3}$ for topsoil (0$20 \mathrm{~cm}$ ) in loamy clay soil in Lake Tana plain of the same region. The soil bulk density increased from 1.13 to $1.34 \mathrm{~g} / \mathrm{cm}^{3}$ from the woodlot center towards adjacent farmland in all directions (Table 4). However, there was no significant difference in 
Citation: Seyoum KA, Alehegn BM, Abtew AA (2021) Effect of Eucalyptus Globules Woodlot Plantation on Selected Soil Physico-Chemical Properties and Wheat Yield in Wogera District, Amhara Region, Ethiopia. J Soil Water Sci 5(1):161-170

bulk density among the distance from the woodlot of the Eucalyptus plantation. Meanwhile, there was not significantly difference in bulk density along with the directions and interaction effect. However, the highest bulk density of $(1.34$ $\mathrm{gcm}^{-3}$ ) was observed at $40 \mathrm{~m}$ distance in the north direction. The findings show that lower bulk density was recorded in the east direction. On contrary, [28] suggested that lower bulk density in croplands as compared to Eucalyptus plantation. The lower bulk density might be because of organic matter accumulation and microbial activity.

\section{Effects of Eucalyptus globules plantation on soil chemical properties}

Soil $\mathrm{pH}$ : According to the finding, the $\mathrm{pH}$ values of the samples taken from the surface layer were ranged from 5.28 to 5.84 (Table 5). Soil pH was not significantly different on the main and interaction effects of the woodlot stand. Generally, lower mean soil $\mathrm{pH}$ values were recorded at the center of the woodlot as compared to soils away from the woodlot which might be due to several mechanisms that release $\mathrm{H}+$ ions, such as soil base cation uptake by the tree, decomposition of organic matter to organic acids and $\mathrm{CO}_{2}$, root respiration and nitrification.

According to [29] rating of soil $\mathrm{pH}$, soils with $\mathrm{pH}\left(\mathrm{H}_{2} \mathrm{O}\right)>8.0$ are characterized as strongly alkaline; 7.4-8.0 as moderately alkaline; 6.7-7.3 as neutral, while soils with $\mathrm{pH}$ of 6.0-6.6, 5.3$5.9,4.5-5.2$ and $<4.5$ were rated as slightly acid, moderately acid, strongly acid and very strongly acid, respectively. According to the study result, the soil was moderately acidic, which ranges between 5.7 and 6.8, which is good for crop production as most nutrients for field crops are available at $\mathrm{pH}$ values of greater than 5.5 [24]. These findings supported by others; lower soil pH recorded under Eucalyptus woodlot plantation as compared to farmlands and grazing lands in Ethiopian central highlands $[26,30]$. Also found that lower $\mathrm{pH}$ under Eucalyptus globules plantations than agricultural lands (Table 6) .

Soil Organic Matter: Soil organic matter was ranged from $2.32 \%$ to $6.42 \%$ (Table 7 ) classified as high Soil organic matter level [31] who classified organic carbon as low (0.6$1.16 \%)$, moderate (1.16-1.74\%) and high (> 1.74\%). There was a significant difference in soil organic matter between the distance of the woodlot and directions $(P<0.05)$. The interaction effect between distance from the woodlot and directions was not significant (Table 7). The soil organic matter was higher at the center of the woodlot than away the woodlot of the nearby cropland that showed a reducing trend with increasing distance from the center of the woodlot towards the crop field within all directions.

Soil organic matter content at the eastern direction was high whereas less content at the western direction was recorded than other directions (Table 7), thus might be passive microbial activities because of late sunlight coming due to shading in the western. The soil organic matter of the woodlot center was 2.76 times higher than the respective soil surface of control ( $40 \mathrm{~m}$ away from the woodlot stand). This variation in soil organic matter with distance away from the woodlot center could be due to accumulation of leaf litters, seeds fall, and dead roots from the tree as compared to the

Table 4: The main effect of Eucalyptus plantation direction and distance on soil texture and bulk density.

\begin{tabular}{|c|c|c|c|c|c|}
\hline & \multicolumn{5}{|l|}{ Soil texture } \\
\hline & & Sand & Clay & Silt & Bulk density \\
\hline \multirow{6}{*}{ 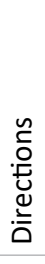 } & East & $37.94 a$ & $27.52 a$ & $34.53 a$ & $1.30 a$ \\
\hline & West & $34.61 a$ & $30.58 a$ & $34.80 a$ & $1.21 \mathrm{a}$ \\
\hline & South & $36.44 a$ & $28.58 a$ & $34.97 a$ & $1.25 \mathrm{a}$ \\
\hline & North & $35.78 a$ & $28.58 a$ & $35.64 a$ & $1.27 a$ \\
\hline & LSD & 5.67 & 6.36 & 5.74 & 0.11 \\
\hline & Significant & Ns & Ns & Ns & Ns \\
\hline \multirow{6}{*}{ 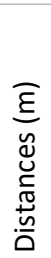 } & Center (0) & $37.94 a$ & $32.40 a$ & $29.65 a$ & $1.13 a$ \\
\hline & 5 & $34.78 a$ & $30.80 a$ & $34.41 a$ & 1.19a \\
\hline & 10 & $35.44 a$ & $28.74 a$ & $35.80 a$ & $1.25 a$ \\
\hline & 15 & $37.11 a$ & $26.52 a$ & $36.36 a$ & $1.26 a$ \\
\hline & 40 & $37.44 a$ & $29.18 a$ & $33.36 a$ & $1.34 a$ \\
\hline & LSD & 8.61 & 9.11 & 6.02 & 0.12 \\
\hline
\end{tabular}

Note: Column refers along a direction and rows refer distance with the same letters are not significantly different at $p<0.05$.

Table 5: The effect of Eucalyptus plantation on soil pH at different distances and directions.

\begin{tabular}{|l|l|l|l|l|l|l|}
\hline \multirow{2}{*}{ Parameter } & Directions & \multicolumn{2}{l}{ Distance $(\mathbf{m})$ from the woodlot } & $\mathbf{1 5}$ & $\mathbf{4 0}$ \\
\cline { 2 - 7 } & Center & $\mathbf{5}$ & $\mathbf{1 0}$ & $5.67 \mathrm{~b}$ & $5.59 \mathrm{~b}$ \\
\hline \multirow{3}{*}{$\mathrm{pH}$} & East & $5.28 \mathrm{a}$ & $5.68 \mathrm{~b}$ & $5.84 \mathrm{~b}$ & $5.63 \mathrm{~b}$ & $5.68 \mathrm{~b}$ \\
& West & $5.28 \mathrm{a}$ & $5.69 \mathrm{~b}$ & $5.58 \mathrm{~b}$ & $5.39 \mathrm{~b}$ & $5.37 \mathrm{~b}$ \\
\hline & North & $5.28 \mathrm{a}$ & $5.50 \mathrm{~b}$ & $5.54 \mathrm{~b}$ & $5.45 \mathrm{~b}$ & $5.51 \mathrm{~b}$ \\
\hline & South & $5.28 \mathrm{a}$ & $5.79 \mathrm{~b}$ & $5.67 \mathrm{~b}$ & & \\
\hline & CV (\%) & 5.01 & & & & \\
\hline
\end{tabular}

Note: Column refers along a direction and rows refer distance with the same letters are not significantly different at $p<0.05$; the first letter represents significance comparison between distances and $\mathrm{b}$ represent between directions. 
Citation: Seyoum KA, Alehegn BM, Abtew AA (2021) Effect of Eucalyptus Globules Woodlot Plantation on Selected Soil Physico-Chemical Properties and Wheat Yield in Wogera District, Amhara Region, Ethiopia. J Soil Water Sci 5(1):161-170

Table 6: The main effect of Eucalyptus plantation directions and distances on soil chemical properties.

\begin{tabular}{|c|c|c|c|c|c|c|c|c|c|}
\hline \multicolumn{10}{|c|}{ Soil chemical properties } \\
\hline & $\mathrm{pH}$ & EC & OM & TN & CEC & Av. $P$ & Ex. Ca & Ex. Mg & Ex. $K$ \\
\hline East & $5.69 a$ & $0.027 a$ & $3.16 a$ & $0.16 a$ & $32.81 a$ & $25.61 a$ & $17.43 a$ & $13.63 a$ & $1.52 a$ \\
\hline West & $5.64 a$ & $0.024 a$ & $2.45 a$ & $0.12 \mathrm{a}$ & $33.15 a$ & $15.17 a$ & $16.96 a$ & $13.97 a$ & $1.54 a$ \\
\hline South & $5.61 a$ & $0.025 a$ & $3.03 a$ & $0.14 a$ & $33.73 a$ & $24.41 a$ & $17.24 a$ & $14.63 a$ & $1.50 \mathrm{a}$ \\
\hline North & $5.45 a$ & $0.028 a$ & $3.04 a$ & $0.15 a$ & $31.77 a$ & $17.39 a$ & $14.62 b$ & $14.88 \mathrm{a}$ & $1.42 a$ \\
\hline LSD & 0.25 & 0.010 & 1.22 & 0.06 & 5.53 & 15.29 & 2.12 & 5.26 & 0.27 \\
\hline \multicolumn{10}{|l|}{ Sig. } \\
\hline Center & $5.28 a$ & $0.030 \mathrm{a}$ & $6.41 a$ & $0.32 \mathrm{a}$ & $35.73 a$ & $8.41 a$ & $14.90 \mathrm{a}$ & $18.07 a$ & $1.44 a$ \\
\hline 5 & $5.66 \mathrm{~b}$ & $0.025 a$ & $3.26 \mathrm{~b}$ & $0.16 b$ & $34.76 a$ & $21.10 b$ & $17.71 a$ & $14.85 a$ & $1.58 \mathrm{a}$ \\
\hline 10 & $5.65 b$ & $0.030 \mathrm{a}$ & $2.97 b$ & $0.14 b$ & $34.57 a$ & $23.80 \mathrm{~b}$ & $16.87 a$ & $13.26 a$ & $1.59 a$ \\
\hline 15 & $5.54 b$ & $0.025 a$ & $2.64 b$ & $0.13 b$ & $32.03 a$ & $19.97 \mathrm{~b}$ & $15.39 a$ & $13.12 a$ & $1.39 a$ \\
\hline 40 & $5.40 \mathrm{~b}$ & $0.024 a$ & $2.82 b$ & $0.13 b$ & $30.10 a$ & $17.71 \mathrm{~b}$ & $16.28 a$ & $15.88 \mathrm{a}$ & $1.43 a$ \\
\hline LSD & 0.34 & 0.014 & 1.70 & 0.08 & 5.41 & 22.68 & 3.53 & 6.24 & 0.33 \\
\hline Sig. & & & & & & & & & \\
\hline
\end{tabular}

Note: Column refers along a direction and rows refer distance with the same letters are not significantly different at $p<0.05$; 'a' letter represents significance comparison between distances and ' $b$ ' represent between directions.

Table 7: The effect of Eucalyptus plantation on soil organic matter and total nitrogen at different distance and direction.

\begin{tabular}{|c|c|c|c|c|c|c|}
\hline \multirow{2}{*}{ Parameters } & \multirow{2}{*}{ Directions } & \multicolumn{5}{|c|}{ Distance $(m)$ from the woodlot } \\
\hline & & Center & $5 m$ & $10 \mathrm{~m}$ & $15 \mathrm{~m}$ & $40 m$ \\
\hline \multirow{6}{*}{$\begin{array}{l}\text { Soil organic matter } \\
\text { (\%) }\end{array}$} & East & $6.42 \mathrm{a}$ & $3.50 \mathrm{~b}$ & $3.45 b$ & $2.82 b$ & $2.89 \mathrm{~b}$ \\
\hline & West & $6.42 a$ & $2.46 \mathrm{~b}$ & $2.47 b$ & $2.56 b$ & $2.33 \mathrm{~b}$ \\
\hline & North & $6.42 a$ & $3.52 b$ & $3.01 b$ & $2.73 b$ & $3.27 \mathrm{~b}$ \\
\hline & South & $6.42 \mathrm{a}$ & $3.57 b$ & $2.96 \mathrm{~b}$ & $2.82 \mathrm{~b}$ & $2.79 \mathrm{~b}$ \\
\hline & CV (\%) & 38.6 & & & & \\
\hline & LSD 0.05 & 2.9 & & & & \\
\hline \multirow{6}{*}{$\begin{array}{l}\text { Soil total nitrogen } \\
\text { (\%) }\end{array}$} & East & $0.32 a$ & $0.17 b$ & $0.17 b$ & $0.14 b$ & $0.14 b$ \\
\hline & West & $0.32 \mathrm{a}$ & $0.12 b$ & $0.12 b$ & $0.12 b$ & $0.11 b$ \\
\hline & North & $0.32 a$ & $0.18 b$ & $0.15 b$ & $0.12 b$ & $0.16 \mathrm{~b}$ \\
\hline & South & $0.32 a$ & $0.18 \mathrm{~b}$ & $0.15 b$ & $0.14 b$ & $0.14 b$ \\
\hline & CV (\%) & 40.3 & & & & \\
\hline & LSD 0.05 & 0.14 & & & & \\
\hline
\end{tabular}

Note: column refers along a direction and rows refer distance with the same letters are not significantly different at $p \quad 0.05$; ' $a$ ' letter represents significance comparison between distances and ' $b$ ' represent between directions

adjacent croplands while the source of soil organic matter outside the woodlot was mostly crop residues which might be removed as a fuel wood and also grazing.

Soil total nitrogen: The finding shown that the total nitrogen contents of the soils were ranged from $0.11 \%$ to $0.32 \%$ (Table 7 ), which could be categorized as medium to high [32]. Who categorized soil total nitrogen rate as very low $(<0.1)$, low (0.1-0.15) medium (0.15-0.25), and high (>0.25). Total nitrogen was significantly different among directions from the woodlot stand (Table 7). In the western direction, lower total nitrogen was observed. However, soil nitrogen was not significantly affected by the distance and directions from the woodlot. Total nitrogen was significantly higher at the center of the woodlot than the adjacent farmland and this might be attributed to more organic matter and nitrogen mineralization at the center of the Eucalyptus plantation. The other reason for high soil nitrogen under Eucalyptus woodlot might be because of the low temperature and very limited radiation reached on the surface of the soil that leads to low volatilization of $\mathrm{NH}_{3}-\mathrm{N}$ [33].
There was a slight decrease in total nitrogen with distances, higher in the eastern direction as compared to other directions. Soil nitrogen concentration showed a decreasing trend with increasing distance from woodlot plantation within all directions (Table 7), this could be due to the effect of intensive and continuous cultivation forced oxidation of organic carbon of field that releases nitrogen from organic matter decomposition [34].

The deep root structure of Eucalyptus can operate as a nutrient pump for leached nitrogen from deep soil or slow down leaching. Soils under Eucalyptus plantation reported as it has larger soil nitrogen due to a long time under tree cover and soil nitrogen mineralization could be increased under Eucalyptus plantation by 11-14 ppm per year [26]. He stated the total nitrogen increased with distance from the Eucalyptus trees, their result showed that near the Eucalyptus stand the soil total nitrogen was significantly larger than the average soil total nitrogen of the field and the nitrogen content declines with increasing distance up to $5 \mathrm{~m}$ away from the woodlot plantation (Table 7). Generally, higher soil nitrogen 
Citation: Seyoum KA, Alehegn BM, Abtew AA (2021) Effect of Eucalyptus Globules Woodlot Plantation on Selected Soil Physico-Chemical Properties and Wheat Yield in Wogera District, Amhara Region, Ethiopia. J Soil Water Sci 5(1):161-170

Table 8: The effect of Eucalyptus plantation on available phosphorus, cation exchange capacity and electric conductivity at different distance and direction.

\begin{tabular}{|c|c|c|c|c|c|c|}
\hline \multirow{2}{*}{ Parameters } & \multirow{2}{*}{ Directions } & \multicolumn{5}{|c|}{ Distance $(m)$ from the woodlot } \\
\hline & & Center & $5 \mathrm{~m}$ & $10 \mathrm{~m}$ & 15 & $40 \mathrm{~m}$ \\
\hline \multirow{6}{*}{$\begin{array}{l}\text { Available } \\
\text { phosphorus (ppm) }\end{array}$} & East & $8.42 a$ & $21.50 a$ & $28.80 a$ & $30.31 a$ & $21.83 a$ \\
\hline & West & $8.42 a$ & $18.70 a$ & $14.92 a$ & $12.62 a$ & $14.47 a$ \\
\hline & North & $8.42 a$ & $18.16 a$ & $21.20 \mathrm{a}$ & $17.02 \mathrm{a}$ & $13.21 a$ \\
\hline & South & $8.42 a$ & $26.04 a$ & $30.31 a$ & $19.93 a$ & $21.36 a$ \\
\hline & CV (\%) & 83.06 & & & & \\
\hline & LSD 0.05 & 27.4 & & & & \\
\hline \multirow{6}{*}{$\begin{array}{l}\text { Cation exchange } \\
\text { capacity } \\
(\mathrm{Cmol} / \mathrm{kg})\end{array}$} & East & $36.73 a$ & $33.96 a$ & $34.44 a$ & 29.19a & $33.66 a$ \\
\hline & West & $36.73 a$ & $35.31 a$ & $31.28 a$ & $30.64 a$ & $34.38 a$ \\
\hline & North & $36.73 a$ & $32.13 a$ & $29.48 a$ & $28.11 a$ & $37.35 a$ \\
\hline & South & $36.73 a$ & $35.67 a$ & $32.92 a$ & $32.45 a$ & $32.89 a$ \\
\hline & CV (\%) & 14.60 & & & & \\
\hline & LSD 0.05 & 8.00 & & & & \\
\hline \multirow{6}{*}{$\begin{array}{l}\text { Electric } \\
\text { conductivity(ds/m) }\end{array}$} & East & $0.03 a$ & $0.026 a$ & $0.03 a$ & $0.023 a$ & $0.023 a$ \\
\hline & West & $0.03 a$ & $0.02 \mathrm{ba}$ & $0.023 \mathrm{ba}$ & $0.026 \mathrm{ba}$ & 0.026ba \\
\hline & North & $0.03 a$ & $0.03 a b$ & $0.03 a$ & $0.026 a b$ & $0.023 a$ \\
\hline & South & $0.03 a$ & 0.026ba & $0.023 a$ & $0.023 a$ & $0.02 a$ \\
\hline & CV (\%) & 40.63 & & & & \\
\hline & LSD 0.05 & 0.01 & & & & \\
\hline
\end{tabular}

Note: Column refers along a direction and rows refer distance with the same letters are not significantly different at $p<0.05$; 'a' letter represents significance comparison between distances and' $b^{\prime}$ represent between directions.

near Eucalyptus trees might be due to the higher nitrogen in the foliage of Eucalyptus tree and low uptake by the tree from the topsoil.

Available soil phosphorus: The available phosphorus contents of the soils were ranged from 8.42 to $30.31 \mathrm{ppm}$ (Table 8) that could be medium to high phosphorus, according to [35] who categorized as very low $(<3)$, low (4-7), medium $(8-11)$, and high ( $>12)$. Soil phosphorus concentration was not affected by the main effects of distance from the woodlot and directions and their interaction effect (Table 8). Soil phosphorus concentration increased with increasing distance from the woodlot in all directions. The mean soil phosphorus concentration at the center of the woodlot was $8.42 \mathrm{ppm}$ lower than the nearby cropland. The lower soil phosphorus accumulation was observed at the center of the woodlot zone than adjacent cropland (Table 8) this could be due to fertilizer application on the adjacent farmland annually. The phosphorus concentration at the western direction was lower towards the cropland.

These findings supported by other works; [36] who reported that the available phosphorus content of farmland is higher than forest lands, which suggests that the annual leftover of phosphorus from fertilizer application is more than obtained from leaf decomposition from trees [26]. Also found that the amount of available phosphorus content in croplands is much larger than in forest and Eucalyptus woodlots. Bewket and Stroosnijder [37] reported that lower available phosphorus content at forest lands is due to a high proportion of phosphorus retained and immobilized by microbes. Another possible reason for low available phosphorus under Eucalyptus woodlots plantation could be due to the lower $\mathrm{pH}$ conditions that can permanently fix phosphorus. Under acid conditions, phosphorus is precipitated as Fe or Al phosphates of low solubility [26], whereby maximum availability of phosphorus generally happens in the range of 6.0 to 7.0 soils $\mathrm{PH}^{\mathrm{H}}$.

Cation exchange capacity: The cation exchange capacity of the soils was not significant for their main and interaction effect between distance and direction from the woodlot, but the higher value of cation exchange capacity was observed at the center of the Eucalyptus woodlot stand (Table 8), this could be depletion of exchangeable bases as a result of intensive cultivation and application of inorganic application fertilizers which reduced the cation exchange capacity. Generally cation exchange capacity decreased with increasing distance from the woodlot within all directions (Table 8). This could be mainly because of the high accumulation of organic matter at the center of the woodlot than the nearby cropland. The higher amounts of soil organic matter under the tree Eucalyptus plantation may imply that more cations would be released to the soil through mineralization as a result; the number of negative charges in the soil would be higher. Our result is confirmed that cation exchange capacity didn't show any significant difference among the land uses in the central highlands of Ethiopia [26].

Soil electrical conductivity: The analysis of variance for soil electrical conductivity revealed that they were not significantly affected by the interaction effect and the main effects of distance and directions (Table 8). This could probably be due to the high rainfall amount that removes base-forming cations from the surface soil. In general, higher soil electrical conductivity at the center of the woodlot than the adjacent cropland, might be due to the increased accumulation of above-ground biomass and associated cation uptake by the tree [38]. Suggested that soils with soil electrical conductivity value of below $0.80 \mathrm{dS} \mathrm{m}^{-1}$ are considered normal and 
suitable for all crop types. The soil electrical conductivity of the soil at the center of the woodlot was $0.03 \mathrm{dSm}^{-1}$ while that beyond the woodlot ranged from 0.03 to $0.02 \mathrm{dSm}^{-1}$ (Table 8). Hence, the soils adjacent to cropland are suitable for most crops. According to [39] in the soil, the determination of the electrical conductivity serves to give an idea of the total quantity of soluble salts, and the degree of salinity. The critical level of electrical conductivity of saturated soil paste extracts (EC) for most crops is $4 \mathrm{dSm}^{-1}$. Soils with EC greater than $4 \mathrm{dSm}^{-1}$ are saline soils. These are considered restrictive for most crops and values as low as $2 \mathrm{dSm}^{-1}$ may affect the more sensitive crops.

Soil exchangeable cations: The values of three primary exchangeable cations (calcium, magnesium, and potassium) were not significantly different within distance, direction, and the interaction effect between distances and direction from the woodlot, but gradually level of exchangeable cations decreasing with increasing distance from the woodlot at all directions (Table 8). There was higher exchangeable magnesium at the center of the woodlot plantation (Table 8), which could be due to the high accumulation of litter under the plantation and decrease their reduction from leaching or erosion. But a lower level of exchangeable calcium and potassium were observed at the of the Eucalyptus woodlot stand (Table 8). Findings supported by [40] who found a lower level of calcium, magnesium, and potassium under Eucalyptus tree at $0-20 \mathrm{~cm}$ soil depth, The result shows that lower exchangeable calcium and potassium cations amount under plantation; this indicated that the Eucalyptus trees absorb these nutrients in standing biomass faster than recycle i.e. nutrients back to the soil. The immobilization of exchangeable bases, especially calcium resulted in lower soil $\mathrm{pH}$ under Eucalyptus plantation at $0-20 \mathrm{~cm}$ soil depth [41]. According to [42] the prevalence of calcium followed by magnesium and potassium in the exchange site of soils is favorable for crop production.

\section{Conclusion and Recommendation}

\section{Conclusion}

The experimental result showed that the Eucalyptus tree and its direction significantly affect crop yield. The crop yield shown that increasing progressively as the distance from the Eucalyptus woodlot stands base increases at all directions, hence higher yields were recorded in the eastern direction whereas lower yields were found in the western direction. This work revealed that there was around 14.2 fold wheat grain yield difference from the stand as compared with the control plot $(40 \mathrm{~m})$ and so did for biomass yield. The Eucalyptus woodlot and its direction have a considerable effect, in that the western direction is more pronounced. This study indicated that under the Eucalyptus woodlot plantation, soils did not vary significantly in texture cation exchange capacity, electric conductivity, potassium, available phosphorus, exchangeable calcium, magnesium and potassium cations, and electric conductivity, on the other hand, soil properties such as organic matter, total nitrogen, soil $\mathrm{pH}$, and bulk density were significantly higher at the center of Eucalyptus woodlot plantation than in the adjacent cropland with decreasing trend with distance from the woodlot stand in all directions. Soil organic matter status under Eucalyptus globules plantation stand is higher, this may be leaf and root litter addition. Higher values of organic matter, total nitrogen, and available phosphorus were found in the eastern direction, but lower in the western direction. Overall, the studied results lead that Eucalyptus globules plantation affects wheat crop yield and selected soil physical and chemical properties. To minimize the adverse effects and improve the environmental importance of Eucalyptus tree plantation, the choice of a suitable site and management methods is very important. Moreover, when grown on cropland, Eucalyptus plantation should be limited to appropriate sites with right the management and utilization so that it will not unfavorably affect neighboring crop productivity.

\section{Recommendation}

For sustainable crop production, the Eucalyptus tree should be planted in the order of west, north, south, and east direction of the cropland. The result of wheat yields reported in this study was under farmer's crop production and management practices which may not be applied the same management practice. So, further study is needed under a controlled experiment in association with this Eucalyptus plantation. Hence, further research required on the effect of its leave on soil physical and chemical properties. Moreover, soil microbial population and their activities with Eucalyptus plantation aspects should be studied in detail.

\section{References}

1. Gizachew K (2017) Expansion of eucalypt woodlot and its factors in Cheha District, Southern Ethiopia. World Scientific News 66: 163-180.

2. Mengist M, Georg G, Sieghardt M (2011) Eucalyptus plantations in the highlands of Ethiopia revisited: A comparison of soil nutrient status after the first coppicing. Master-Mountain Forestry Program.

3. Egata DF, Desta WD (2020) Determination of optimum spacing and harvesting age of citron scented gum (Eucalyptus citriodora H.) for maximum biomass and essential oil yield at wondo genet, South Ethiopia.

4. Jaleta D, Boniface Mbilinyi, Henry Mahoo, et al. (2016) Eucalyptus expansion as relieving and provocative tree in Ethiopia. Journal of Agriculture and Ecology Research International6: 1-12.

5. Dessie AB, Abtew AA, Koye AD (2019) Determinants of the production and commercial values of Eucalyptus woodlot products in Wogera District, Northern Ethiopia. Environmental Systems Research 8.

6. Oballa P, Konuche PKA, Muchiri MN, et al. (2010) Facts on growing and use of Eucalyptus in Kenya.

7. Jenbere D, Lemenih M, Kassa $H$ (2012) Expansion of eucalypt farm forestry and its determinants in Arsi Negelle District, South Central Ethiopia. Small-Scale Forestry 11: 389-405.

8. Liang J, Reynolds T, Wassie A, et al. (2016) Effects of exotic Eucalyptus spp. plantations on soil properties in and around sacred natural sites in the northern Ethiopian Highlands. AIMS Agriculture and Food 1: 175-193.

9. Alemie TC (2009) The effect of eucalyptus on crop productivity, and soil properties in the Koga Watershed, Western Amhara Region, Ethiopia, Cornell University. 
Citation: Seyoum KA, Alehegn BM, Abtew AA (2021) Effect of Eucalyptus Globules Woodlot Plantation on Selected Soil Physico-Chemical Properties and Wheat Yield in Wogera District, Amhara Region, Ethiopia. J Soil Water Sci 5(1):161-170

10. El-Amin, Diab El, Ibrahim S (2001) Influence of Eucalyptus cover on some physical and chemical properties of a soil in Sudan. Communications in soil science and plant analysis 32: 2267-2278.

11. Oehl F, Laczko E, Bogenrieder A, et al. (2010) Soil type and land use intensity determine the composition of arbuscular mycorrhizal fungal communities. Soil Biology and Biochemistry 42: 724-738.

12. Ahmed M, Tariq Husain, Sheikh Ah, et al. (2006) Phytosociology and structure of Himalayan forests from different climatic zones of Pakistan. Pak J Bot 38: 361-383.

13. Mouazen AM, Karoui R, Baerdemaeker J De, et al. (2005) Classification of soil texture classes by using soil visual near infrared spectroscopy and factorial discriminant analysis techniques. Journal of near infrared spectroscopy13: 231-240.

14. Nelson DW, Sommers LE (1996) Total carbon, organic carbon, and organic matter. Methods of soil analysis: Part 3 Chemical methods 5: 961-1010.

15. Olsen SR, Cole CV, Watanabe FS, et al. (1954) Estimation of available phosphorus in soils by extraction with sodium bicarbonate. U.S. Dept. of Agriculture.

16. Rayment GE, Lyons DJ (2011) Soil chemical methods: Australasia. CSIRO publishing 3 .

17. Chapman HD (1965) Cation-exchange capacity. Methods of Soil Analysis: Part 2 Chemical and Microbiological Properties 9: 891-901.

18. Blake GR, Hartge K (1986) Bulk density. Methods of soil analysis: Part 1 Physical and mineralogical methods 5: 363-375.

19. Sharma A, Sah V (2020) Comparative growth, yield and yield attributes of wheat under poplar and eucalyptus based agroforestry system. Plant archives 20: 47-52.

20. Alebachew M, Amare T, Wendie M, et al. (2015) Investigation of the effects of eucalyptus camaldulensis on performance of neighbouring crop productivity in western Amhara, Ethiopia. Open Access Library Journal 2: 1-10.

21. Odhiambo H, Ong CK, Deans JD, et al. (2001) Roots, soil water and crop yield: Tree crop interactions in a semi-arid agroforestry system in Kenya. Plant and soil 235: 221-233.

22. Khaliq A, Khan RA, Waqar Ahmed, Et al. (2004) Effect of eucalyptus camaldulensis on the yield of wheat and maize crops after reducing tree density. Pak J Agri Sci 41: 62-64.

23. Ralhan PK, Singh A, Dhanda R (1992) Performance of wheat as intercrop under poplar (Populus deltoides Bartr.) plantations in Punjab (India). Agroforestry systems 19: 217-222.

24. Landon JR (2014) Booker tropical soil manual: A handbook for soil survey and agricultural land evaluation in the tropics and subtropics. Routledge.

25. Sharu M, Yakubu M, Noma SS, et al. (2013) Characterization and classification of soils on an agricultural landscape in Dingyadi District, Sokoto State, Nigeria. Nigerian Journal of Basic and Applied Sciences 21: 137-147.

26. Yitaferu B, Abewa A, Amare T, (2013) Expansion of eucalyptus woodlots in the fertile soils of the highlands of Ethiopia: Could it be a treat on future cropland use? Journal of Agricultural Science 5: 97-107.
27. Chanie T, Collick Amy S, Adgo E, et al. (2013) Eco-hydrological impacts of Eucalyptus in the semi humid Ethiopian Highlands: The lake tana plain. J Hydrol Hydromech 61: 21-29.

28. Selassie YG, Ayanna G (2013) Effects of different land use systems on selected physico-chemical properties of soils in Northwestern Ethiopia. Journal of agricultural science 5: 112120.

29. Tekalign T, Haque I, Aduayi E (1991) Soil, plant, water, fertilizer, animal manure and compost analysis. Working document.

30. Zewdie M (2008) Temporal changes of biomass production, soil properties and ground flora in Eucalyptus globulus plantations in the central highlands of Ethiopia.

31. Atumo TT (2018) Evaluation of forage type cowpea (Vigna unguiculata L. Walp.) accessions for dry matter yield in lowlands of Southern Ethiopia. Advances in Life Science and Technology 66: 21-26.

32. Mulumba LN, Lal R (2008) Mulching effects on selected soil physical properties. Soil and Tillage Research 98: 106-111.

33. Wedajo Abdi M (2019) Localizing ethiosis fertility map based fertilizer type recommendation for maize (Zea mays L.) in coffee and spice production belt in yeki district, Southwest of Ethiopia, Jimma University.

34. Adhanom D, Toshome $T$ (2016) Characterization and classification of soils of Aba-Midan sub watershed in Bambasi Wereda, West Ethiopia. International Journal of Scientific and Research Publications 6: 390-399.

35. Josan M, Nair V D, Harris W G, et al. (2005) Associated release of magnesium and phosphorus from active and abandoned dairy soils. J Environ Qual 34: 184-191.

36. Kebede Y, Raju S (2011) Effect of land use/land cover change on soil properties in the Hare River Watershed, Ethiopia. The Ecoscan, An International Quarterly Journal of Environmental Sciences 5: 69-74.

37. Bewket W, Stroosnijder L (2003) Effects of agroecological land use succession on soil properties in chemoga watershed, blue nile basin, Ethiopia. Geoderma 111: 85-98.

38. Berhe DH, Agena Anjulo, Abdu Abdelkadir, etal. (2013) Evaluation of the effect of ficus thonningii (blume) on soil physicochemical properties in ahferom district of tigray, Ethiopia. Journal of Soil Science and Environmental Management 4: 35-45.

39. Shirokova Y, Forkutsa I, Sharafutdinova N (2000) Use of electrical conductivity instead of soluble salts for soil salinity monitoring in Central Asia. Irrigation and Drainage Systems 14: 199-205.

40. Mugayi E (2019) Impacts of eucalyptus plantation on soil physico-chemical properties in bamunanika sub-county, luwero district, Uganda, Makerere University.

41. Mensah AK (2016) Effects of eucalyptus plantation on soil physico-chemical properties in thiririka sub-catchment, kiambu County, Kenya. Kenyatta University.

42. Buraka T, Sorsa Z, Lelago A (2016) Response of Faba Bean (Vicia Faba L.) to phosphorus fertiliizer and farm yard manure on acidic soils in boloso sore woreda, wolaita zone, Southern Ethiopia. Food Science and Quality Management 53: 15-21. 